\title{
FINANCING PROJECTS OF CULTURAL INSTITUTIONS ENCOURAGING THE YOUNGEST CONSUMERS PARTICIPATION IN CULTURE
}

\section{DOROTA BALCERZYK}

General Tadeusz Kościuszko Military University of Land Forces, Wrocław, POLAND

e-mail: d.balcerzyk@wso.wroc.pl

RECEIVED
ACCEPTED
JEL
CLASSIFICATION

KEYWORDS

ABSTRACT
7 August 2017

15 December 2017

D02, H52, H75, J18, Z13

cultural institutions, public organizations, participation in culture, funding for culture

Participation in culture is a human activity that can undoubtedly fill free time and is universally approved. Main roles that cultural institutions play include shaping and educating a consumer, who in the future will be not only a conscious and systematic recipient, but also a culture carrier. The article deals with the issue of subsidizing cultural institutions' projects aimed at young recipients with receptive minds. The results of research describe the feelings of managers of cultural institutions in relation to co-financing their activities. They also indicate the extent of utilization of various sources of project funding by institutions of culture.

\section{Introduction}

Cultural institutions are part of a broad market of free time management of a part of the society. As public institutions, they should best fulfill their role as culture promoter and cultivator, which in today's competitive environment is not an easy task, especially considering budgetary constraints. In this context, financial support for these institutions' activities is gaining in importance. 


\section{Contribution of cultural institutions to shaping the habits of participation in culture in the youngest consumers - literature review}

Man's free time as one of forms of human life, the social reality that exists today and existed in the past, is taken up by the social sciences, including psychology, pedagogy, economics and sociology. The classic, French sociologist J. Dumazidier (1962, p. 27) describes free time as a category of behavior that encompasses all activities that an individual can devote himself/herself to, whether for leisure, entertainment, development of his/her knowledge or for selfless learning, as well as voluntary participation in social life after the completion of professional, family and social duties. According to J. Dumazidier (1974, p. 165), free time is only the time that satisfies the conditions such as the voluntary choice of actions, the personal nature of the activities and the lack of utilitarian benefits.

In economics, free time is perceived as a time of consumption in which various social needs are addressed. It requires a time management strategy (Jung, 1989). The market of services such as tourism, gastronomy, entertainment, media, but also those in the field of culture or wellness offer leisure time activities. Economic research deals with the diagnosis and predictions as to these services (Kolny, 2013). Economists understand leisure as both a consumption market and a labor market (an employer). Economists also see free time as a sort of "surplus" generated by the economy when analyzing the problems of choice between income growth and the amount of free time. It is worth emphasizing also the value and valuation of leisure time, not only as autotelic values, but also as utility and economic ones, or those satisfying specific needs: consumption, rest, regeneration (reconstruction of workforce). Leisure time is also considered as an additional time of developmental and creative functions (Jung, 1989, pp. 88-103).

Leisure time can be spent on developing interests, but also on shaping habits, participation in culture and cultural activity. Participation in culture consists of specific forms of social activity, which are oriented at the reception and interpretation of works of art (Golka, 1996; Kaplan, 1989; Kisiel, 2003). These behaviors are important for the proper functioning of each community and an individual as well. This is primarily due to the importance of culture in social life. Participation in culture is the most desirable element, as it provides the benefits both to the participant and to the community or society (social system) within which certain actions take place. Maybe that is why the increase in the level of participation in culture is one of the priorities of the European Union's social policy. Broad cultural participation fosters the development of a knowledge society. Not only is it important as an area of aesthetic experiences that delivers enjoyment to a recipient, it is also the area of such important community experiences that create or modify the system of social relationships and bonds. Shaping cultural activity habits is one of the means to equalize social opportunities and invest in human capital.

Research shows that the mass media (the Internet access, watching TV), tourism and recreation are still among the main forms of spending leisure time, which enjoy the greatest social interest without which we cannot even imagine the opportunity to spend that time. Despite being given greater social recognition the forms associated with cultural participation and the use of cultural institutions are less common and desirable (Kolny, 2013, pp. 183185; Pietta, 2014, pp. 79-103).

In the perspective of the all-inclusive culture (Melosik, 2013, p. 53), where everything is mixed and the instant culture reigns traditional leisure activities go into the background. Cultural institutions are primarily responsible for the change of the situation, as due to the purpose of their establishment, which was specified in the provisions of the Act of 25 October 1991 on the organization and management of cultural activities. The main task of a cultural 
institution is the activity related to the maintenance and development of cultural heritage (Olechnicki, Załęcki, 1997, p. 85). However, as set up in the provisions, they are organizational forms of cultural activity, which within the meaning of this Act, consists in the creation, dissemination and protection of culture. Institutions of culture include in particular theaters, operas, philharmonic orchestras, orchestras, film institutions, cinemas, museums, libraries, community centers, art centers, art galleries and research and documentation centers in various cultural fields (Act OECA, 1991. There are various criteria for classification of cultural institutions. Depending on the accepted classification criterion, numerous types, categories and subcategories of cultural institutions can be distinguished. Following the criterion of ownership (most frequently in relation to the establishment (setting up), supervision and funding), the following cultural institutions are distinguished: public (government and local government at three levels of voivodeship, district and municipality sub-categories:), private, civil (NGO) - associations and cultural foundations and mixed categories (e.g. music camps, companies with public capital share) (Kaczmarek, Gruszka, 2017). Due to the criteria of professionalism, professional, semi-professional, non-professional cultural institutions can be distinguished.

When it comes to the economic assumptions, the criterion of commerciality is taken into account, hence the division into commercial and non-commercial cultural institutions. The Article 11 of the Act on the organization and management of cultural activities introduces the division of cultural institutions into artistic ones and others. Artistic institutions are cultural institutions established for the purposes of artistic activity in the field of theater, music, dance, with the participation of artists and performers, mainly theaters, philharmonic orchestras, operas, operettas, symphonic and chamber orchestras, song and dance ensembles and choral ensembles. Other than artistic ones are those cultural institutions, which include, for instance, film institutions, cinemas, museums, libraries, cultural centers, art centers, art galleries and research and documentation centers (Act OECA, 1991) are other than artistic institutions. It should be noted that a certain institution can and often belongs to several categories or types depending on the criteria adopted.

Institutions of culture, regardless of whether artistic or other ones are considered, operate based on the foundation act and the statute authorized by the organizer. Such an act specifies the subject of activity, the name and seat of the institution, and the fact that the given institution is an artistic institution.

The nature of a cultural institution's activity is determined not only by its category of affiliation but also the source of finances, which depend on the institution's legal status. Cultural institutions may be run by local government units, since cultural activity is included in their own mandatory assignments, and can be organized by legal persons, natural persons and organizational units which have no legal personality. Institutions of culture, which are organized by local government units, may receive targeted subsidies for tasks covered by state patronage, subsidies for financing or co-financing the costs of carrying out investment from the state budget from the part that is at the disposal of the minister competent for culture and protection of national heritage (Act OECA, 1991).

Various factors influence the development and attractiveness of a cultural institution's offer. Undoubtedly, in the age of competition, the external support for these institutions' activities is of crucial importance. Performing statutory tasks is often associated with the search for new forms of activity or cooperation with external institutions and solutions enabling them to function on the market. 


\section{Methodology and the conduct of research}

The purpose of the research was to assess the financial support for cultural institutions, that would facilitate the organization of forms of participation in culture targeted at early school children. The article presents the research material acquired by means of the diagnostic survey method. Data obtained from the analysis of questionnaires that had been previously sent to the executives of cultural institutions located in the city of Wroclaw were supplemented using the method of analysis of secondary sources - websites of the institutions under investigation. Institutions were selected for the study by the criterion of having an offer accessible to early-school-age children. The research sample was chosen after analyzing the data obtained from the Public Information Bulletin of the Wrocław City Hall, the Culture Institution Register, as well as the websites of cultural and educational institutions located in Wrockaw.

The study included four Youth Culture Houses: the Fabryczna Youth Culture Houses, the Krzyki Youth Culture Houses, the Śródmieście Youth Culture Houses and the Mikołaj Kopernik Youth Culture Center (also called the Center for Cultural Education of Children and Youth) (EIW, 2014); theaters: the Puppet Theater and the Polish Theater, musical scenes: the Capitol Musical Theater, the Wroclaw Opera, the Witold Lutoslawski Philharmonic (since 2014 the National Forum of Music); museums: the Wroclaw City Museum, the National Museum in Wroclaw (and its two branches), the Museum of Post and Telecommunications, and cinemas: Multikino (two branches), Helios, Cinema City and the New Horizons Cinema. Moreover, as to the offer addressed to children at the early school age, the study included: the Wroclaw-Zachód Cultural Center, the Agora Cultural Center, the Discovery Center Centennial Hall and the Wroclaw Zoo. A total of 20 surveyed institutions correctly completed the questionnaires. The data analyzing purpose, they were assigned to five categories of institutions: Youth Culture Centers, theaters and music scenes, museums, cinemas and others.

\section{Results of own research - Financial support for projects of cultural institutions that oryanize leisure forms aimed at the youngest consumers}

The issue of funding is the primary concern for cultural institutions. However, it turns out that the cultural institutions under study do not experience a significant financing problem, especially regarding the offer organized for children in early school age. Figure 1 depicts results obtained to the question of whether the financial support for individual entities (such as foundations, associations, municipal, district and ministerial measures, sponsoring, etc.) is sufficient in relation to the organization of forms addressed to early school children.

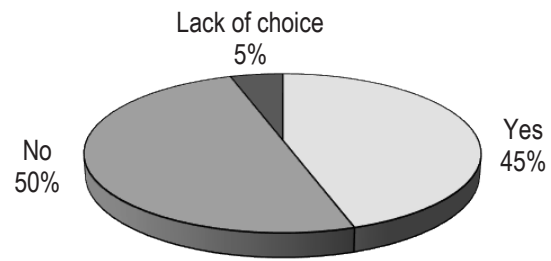

Figure 1. Evaluation of financial support for cultural institutions for the organization of leisure forms for children at the early school age

Source: own study, Wrocław 2014. 
Respondents' answers divided almost in half. As many as $50 \%$ of them believed that the financial support for individual entities was insufficient. However, a similar percentage, as $45 \%$ rated financial support as sufficient. Only $5 \%$ of respondents did not express their opinion.

The financial support assessment provided by the studied institutions is shown in Figure 2 as the dependence of the respondents' answers on their belonging to a particular category of institutions.

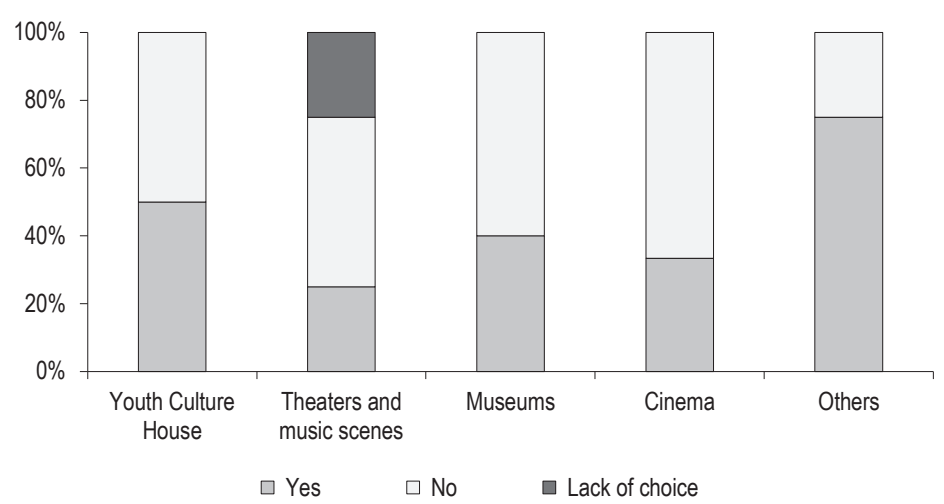

Figure 2. Evaluation of financial support for cultural institutions for the organization of leisure forms for children at the early school age depending on belonging of respondents to particular categories of institutions

Source: own study, Wrockaw 2014.

The respondents assigned to the category others were most satisfied with financial support. $75 \%$ of them accepted the current level of support. The answers were split in half among the respondents from the Youth Culture Centers. Most of the respondents from the Wrocław museums (60\%) rated financial support as insufficient. The cinema representatives were the most dissatisfied group, of which $67 \%$ assessed it as insufficient.

It seemed interesting to gather information on entities that take on a role of supporting financially cultural institutions, which greatly facilitates the organization of forms addressed to young consumers. Hence, the executives of the surveyed institutions were asked in the survey questionnaire to indicate institutions - entities supporting their finances in the development of offer for children at the early school age. Respondents were asked a semiopen question, where they could select groups of entities supporting them financially from the proposed cafeteria, however they also had the possibility to add others than those mentioned. The analysis of responses to the above question is presented in Figure 3. The research clearly indicates the greatest support of cultural institutions from urban and provincial funds (12 indications). When choosing the above entities from the cafeteria, respondents suggested supplementing the list with the Department of Education and the Department of Culture of the Wroclaw City Office within the framework of a yearly grant for their activity, while the Marshal Office of the Lower Silesian Voivodeship was mentioned only once. 


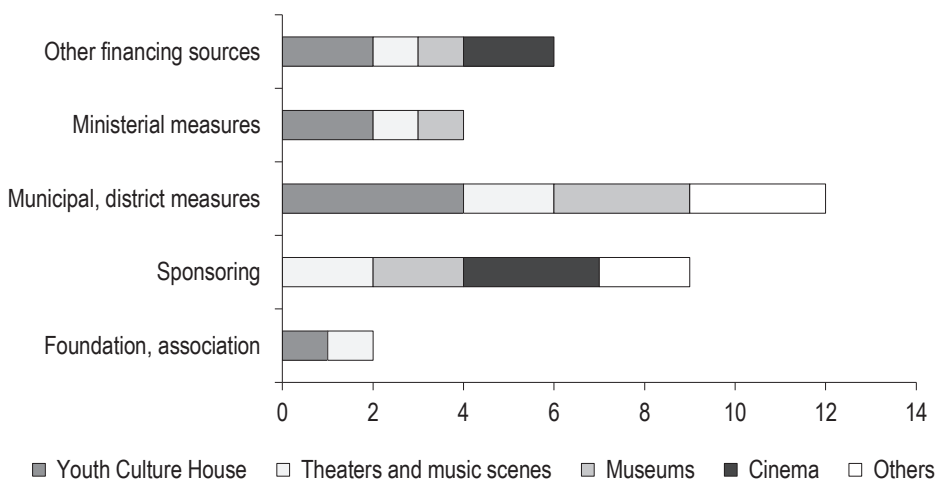

Figure 3. Entities supporting financially the institutions from individual categories in the organization of leisure forms for children at the early school age (multiple choice question)

Source: own study, Wroclaw 2014.

The second most common indication was the support on the part of the so-called sponsorship (9 indications). Opel Vivaro Wroclaw, the RAGTIME Wroclaw music store, Aquapark, Projekcja EDU, Hasta Wholesale, Słodkie Czary Mary, Dot Wholesale, Dagny Wholesale, ZOO, PSS Społem, Astrum Publishing House, czas dzieci.pl, przedszkola.edu.pl and Nordea Company were among the sponsors.

The were followed by other sources of funding including own funds, parents' donations, Parents' Council, support of the Polish Film Institute for the project The First Visit to the Cinema, KGHM and the Council of the Karłowice-Różanka Housing Estate (6 indications).

Few of the respondents (4 indications) mentioned support from the Ministry of Culture and National Heritage. Only two institutions indicated support from associations, namely MDK Cultural Association at MDK "Śródmieście" and "Promyk słońca" Association.

By analyzing the answers to the question about entities supporting financially the organization of free time activities for early school children, one cannot fail to notice the dependence between the categories of institutions that the respondents come from and the indicated supporters. Youth Culture Houses benefit from the support of a variety of entities, aside from sponsoring. Theaters and music scenes benefited from financial support from a wide range of entities and sources. Museums in Wroclaw showed that they largely used municipality and district funds and sponsorship as well as from ministerial measures and other sources in the next place, while leaving out entities such as foundations and associations. Cinema indicated only two categories of financial supporters: sponsorship and other sources. Institutions from other categories pointed to subsidies from municipal and district funds and from sponsorship.

\section{Research limitation}

The premise of choosing the survey method to conduct research in cultural institutions was to preserve the relative anonymity of the institution. In the pilot studies, respondents often indicated this as the condition of their consent for research. The survey method, on the one hand, makes it possible to freely express one's opinion on 
a given topic, however lengthy waiting time for feedback and the lack of direct contact with a respondent constitute its shortcomings. This contact was usually limited to a temporary meeting with the director or manager of the institution when asking for filling in the questionnaire. On the other hand, the questionnaire was usually collected from a secretary. It should be noted, however, that the specificity of the issue being addressed did not require direct contact with the respondent. The limitations of the survey method did not affect the quality of results, but only on the researcher's experience (extended in the period of results collection).

\section{Conclusions}

Early school age in children is an optimal time for cultural institutions to take active part in the education of children and shaping their leisure time habits. Children's free time can be devoted to cultural participation. Cultural institutions take this fact into consideration in their activities promoting culture. As the respondents point out, the offer addressed to such a young consumer requires them to take non-standard actions generating additional cost. In particular, this problem concerns artistic institutions, whose customers are adults as a rule. In this situation it seems that external financial support can greatly facilitate the organization of the offer of a cultural institution aimed at children at the age when the acquisition and encouragement of customs and cultural styles is greatest. The results of the study allow the conclusion that the investigated cultural institutions reach for various forms of financial support in order to organize forms directed at children at the early school age. The feelings of the respondents regarding the evaluation of support received in relation to expectations are satisfactory. It would seem that the vast majority of respondents would assess financial support as insufficient. However, only half of the respondents gave it such assessment. The research allows the statement that cultural institutions usually receive additional financial support from state funds. Sponsorship is also a significant part of the financing. However, the interest of companies in sponsoring culture is increasingly noticed in social reality Undoubtedly, the advantage is reciprocal. Institutions of culture deal with budgetary problems effectively. On the other hand, the cooperation of companies with institutions approved by the society positively influences their image. By adding the cultural institution to the all-inclusive package for the society, it will have the opportunity to disseminate.

\section{References}

Dumazedier, J. (1962). Vers une civilization du loisir? Paris: Editions du Seuil.

Golka, M. (1996). Socjologiczny obraz sztuki. Poznań: Ars Nova.

Jung, B.H. (1989). Ekonomia czasu wolnego. Zarys problematyki. Warszawa: Wydawnictwo Naukowe PWN.

Kaczmarek, G, Gruszka, E. (2017). Menedżerowie, animatorzy, edukatorzy, urzędnicy, twórcy?... Kultury. Raport w oparciu o indywidualne wywiady pogłębione. Retrieved from: http://kultura.gminick.megiteam.pl/download/is_www/Menad_erowie_ animatorzy_edukatorzy_urz_dnicy_tw_rcy_kultury.pdf (15.08.2017).

Kaplan, M. (1989). The Arts. A Social Perspective. New York: Fairleigh Dickinson Univ. Press.

Kisiel, P. (2003). Współczesna kultura artystyczna. Społeczny wymiar uczestnictwa. Kraków: Akademia Ekonomiczna.

Kolny, B. (2013). Rynek usług zagospodarowujący czas wolny - diagnoza i perspektywy rozwoju. Katowice: Uniwersytet Ekonomiczny. Lewandowski, M. (2013). Sprawność zarządzania instytucjami kultury. Studia Ekonomiczne Uniwersytet Ekonomiczny w Katowicach, $168,139-151$.

Melosik, Z. (2013). Kultura popularna i tożsamość młodzieży. Kraków: Impuls.

Olechnicki, K., Załęcki, P. (1997). Słownik socjologiczny. Toruń: Graffiti BC. 
Pięta, J. (2014). Pedagogika czasu wolnego. Nowy Dwór: FREL.

Act OECA 1991. The Act of 25 October 1991 on organizing and engaging in cultural activity, Art. 1 Chapter1.

EIW (Education in Wroclaw) (2014). Retrieved from: http://www.edu.wroclaw.pl/wps/portal/edu-dev/main22/placowki (28.10.2014).

Rejestr instytucji kultury. Retrieved from: http://bip.um.wroc.pl/contents/159 (28.12.2013).

Cite this article aS: Balcerzyk, D. (2018). Financing projects of cultural institutions encouraging the youngest consumers participation in culture. European Journal of Service Management, 1 (25), 7-14. DOI: 10.18276/ejsm.2018.25-01. 